\title{
The Relationship between Crime Prevention Through Environmental Design (CPTED) and Criminal Geography (CG)
}

\section{István Jenő MOLNÁR ${ }^{1}$}

\begin{abstract}
Knowledge of crime trends and permanent monitoring of criminal acts are the fundaments of successful crime prevention. Neither the need for investigating the structure, dynamic and volume of crime is new-fangled, nor the examination of the relationship between spatial distribution of crime and crime prevention through environmental design (CPTED). However, the philosophy of CPTED has changed significantly over the last two decades, with a focus on the role of individuals and the communities, their involvement and the need to encourage them to act. How has this paradigm shift changed the relationship between these two areas? How trivial will be in the future to use CPTED tools in those areas where we detect rather serious criminal infection?
\end{abstract}

Keywords: crime prevention, CPTED, criminal geography, architecture, urban planning

\section{Introduction}

One of the decisive factors of our socialisation is the environment where we live. The physical space surrounding us, as well as the interactions in this space, can fundamentally determine the behaviour of an individual, a group or a community. When we are talking about interactions, most of the time we are focusing on people-to-people contacts, but there is a close bond between people and environment. So, spaces, buildings, built and natural environment, where our activities are taking place, affect us and influence our behaviour. This impact becomes interaction when we create these spaces and make them more beautiful, more attractive, cleaner, or even safer.

The environment is therefore a key factor in daily lives, so we must pay special attention to shaping it. Not only in aesthetics and urbanism, but also in terms of living and security. The reason is trivial: the built environment, especially in terms of residential design, is believed to be one of the factors influencing crime and the level of

István Jenő MOLNÁR, dr., lieutenant colonel, National Crime Prevention Council, Head of Strategy Department, PhD student at the University of Public Service

https://orcid.org/0000 00032378 8868; ijeno.molnar@gmail.com 
fear of crime. This is the underlying reason why the environment can be a determinative element in crime prevention, too.

But what does crime prevention mean? When we are talking about crime prevention, many people think of various activities, because the range of possible associations is endless. We 'make' crime prevention as a private person by closing the door, by arming the alarm system or by using CCTV-s (close circuit television), by downloading anti-virus software and so on. Of course, police officers prevent crime by patrolling on the streets or when they inform the kids in the school about crime and about the behaviour to avoid. In this relation researchers can prevent crime when they make their own theories about the mechanism of crime. Moreover, in the last few years crime prevention could be interpreted as an economic sector.

Based on the above, it is not a coincidence that none of the definitions of crime prevention attempt - even by way of example - to enumerate the possible activities. It can be assumed with sufficient certainty that the reason is the strange paradox of crime prevention:

'The precondition for developing and implementing a preventive intervention is the perpetration of the crime itself. All this means that the prerequisite for choosing the right methods is to identify the characteristics of committed behaviours. Identification makes it possible to uncover trends and underlying behaviour of offences, so we can prepare the potential victim.'

Because of this background of uncertainty and dynamic change, it would be difficult to list all possible and necessary crime prevention measures.

So, almost every definition contains only goals, which goals can be interpreted as a framework and as the essence of crime prevention, which is essentially the prevention of becoming a victim and perpetrator and of increasing the subjective sense of security (or fear of crime).

If we want to be successful in crime prevention, we must constantly monitor the characteristics of crime, not only in terms of trends, but also in terms of crime scene, because there are many criminal acts which are fixed in location and time.

At this point crime prevention and criminal geography (CG) can be closely linked, because CG is able to show us the synergy between criminal conducts and geographical juxtapositions. The spatial relationships of crime is obviously determined - except for online criminal activities - by the built environment, for example in case of burglaries, which are committed mostly in those areas where people leave their home during the day without any surveillance.

As I already mentioned, the definitions of crime prevention are based on the philosophy of 'laissez-faire', so it is not surprising that the shaping of built environment can be a crime prevention tool. It is called crime prevention through environmental design (CPTED): it has become a popular urban planning approach to prevent crime

István Jenő Molnár, 'A bűnmegelőzés értelmezése és magyarországi fejlődése', in A bünüldözés és a bünmegelőzés rendészettudományi tényezői (Pécs: Magyar Hadtudományi Társaság Határőr Szakosztály Szakcsoportja, 2019), 80. 
and mitigate fear of crime through the improvement of physical environments. Timothy D. Crowe (1950-2009) defined CPTED as follows: 'the proper design and effective use of the built environment can lead to a reduction in the fear and incidence of crime, and an improvement of the quality of life'. ${ }^{3}$

Nowadays we have a new expression for CPTED: the thought of environment-sensitive crime prevention was born in 2019. ${ }^{4}$ According to the authors it can describe more accurately the essence of this type of crime prevention. In their view, CPTED is not only about the built environment and design, but also about the environment that contains individuals and communities.

In summary, the two disciplines - being focused on physical spaces - are interconnected in several ways, insomuch that the development of CPTED is partly explained by early criminal geography and the closely related criminal statistics research.

In this study, I try to present the common roots, findings, and theories of these two disciplines, as well as the practical applications of CPTED in the context of criminal geography.

\section{The classical theories of CG in the light of positivist criminology}

The birth of positivist criminology was an important station of the history of criminology in the first half of the $19^{\text {th }}$ century, because the representatives of this approach were the first to attempt to apply official data and statistics to explaining criminality. They realised that crime is a mass phenomenon, so they started analysing the social and economic factors of delinquency. In their opinion - for example in that of Guerry and Quetelet, which will be described in detail later -, crime and guilty behaviour is not only a biological or psychical factor, but a behaviour induced by ecological influences.

The ecological approach of criminological theory is also referred to as the statistical, geographical, and cartographical school. This type of criminology focuses on the interrelationship between human organisms and the physical environment, and so does CG.

But what is CG? It may be interesting, but it is not a self-contained discipline, because its subject, terminology, methods and epistemological principles are based on the knowledge of criminology, sociology and social-geography, in addition there is a close connection with demography, ethnography, psychology, architecture and finally with cartography and GIS (geographic information system). ${ }^{5}$

Timothy D. Crowe, Crime prevention through environmental design: Applications of architectural design and space management concepts, $2^{\text {nd }}$ edition, National Crime Prevention Institute (Boston: Butterworth-Heinemann, 2000), 1.

4 Barabás A. Tünde et alii, 'Környezetszenzitív megelőzés az okos városokban', Kriminológiai Tanulmányok 56 (2019), 121-142.

5 Antal Tóth, A bünözés térbeli aspektusainak szociálgeográfiai vizsgálata Hajdú-Bihar megyében, PhD Dissertation, University of Debrecen, 2007, 11. 
CG is an inter- and subdiscipline which deals with the spatial and temporal aspects of crime as a social mass phenomenon, and studies crime so as to find hotspots where crimes are likely to occur. The information is used to plan safer living spaces and to prevent crimes. Despite its great contribution to describing crime patterns by different spatial characteristics, it has limitations in explaining the direct causes of crime, the dynamics of the underlying process and individual human behaviours.

Despite this criticism, CG gives us indispensable information about the spatial structure, dynamic, volume, tendency, and territorial intensity of crime. But who and how made the first CG measurements?

André-Michel Guerry (1802-1866) was credited with being a pioneer in relying exclusively on shaded areas of maps in order to describe and analyse official crime statistics. 'Comparing poverty with crime, Guerry found that the wealthier areas of France had more property crimes, while the poor and rural regions had less property crimes. ${ }^{6}$ Now it is trivial, but he was one of the first experts who realised that burglary and theft occurs where more goods are available. He also realised that the rate of violent and personal crimes were higher in rural areas, which rates were consistent annually.

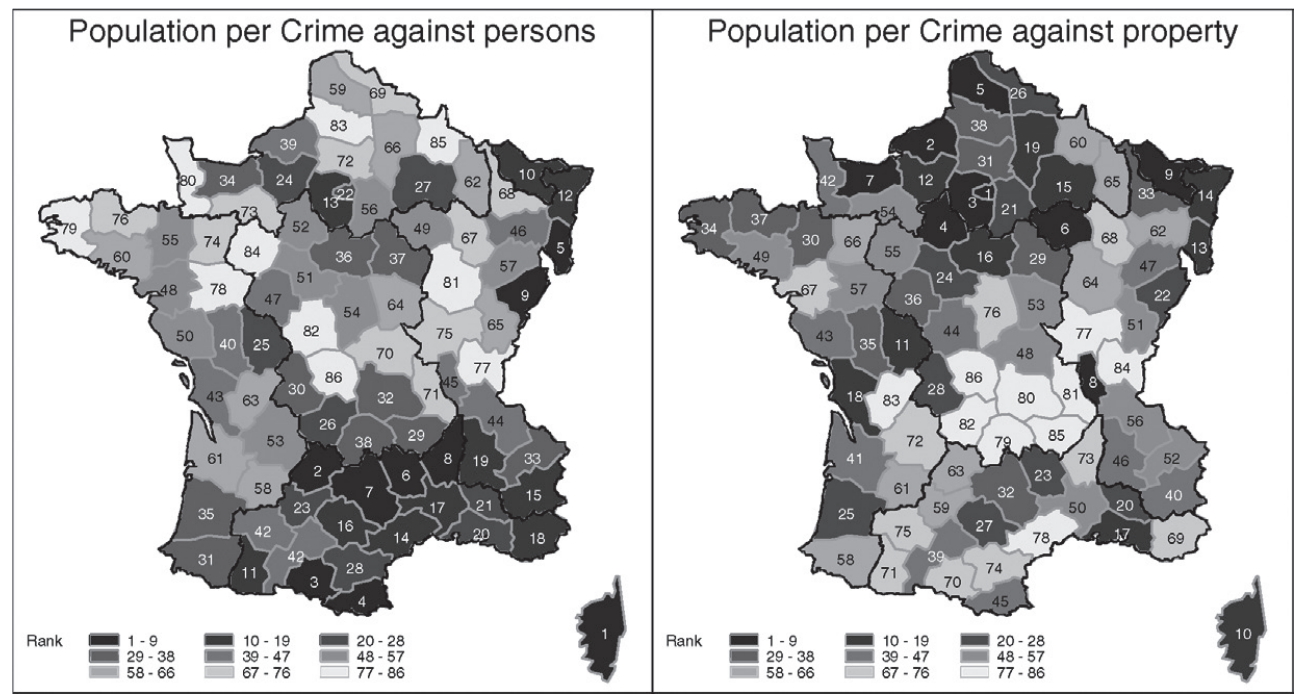

Figure 1: Population per crime against persons and property, made by Guerry. Source: Michael Friendly, 'Moral Statistics of France - Challenges for Multivariable Spatial Analysis', Statistical Science 22 (2007).

In 1829, he cooperated with the Italian geographer Adriano Balbi (1782-1848) and they produced together a large, single-sheet set of three shaded maps comparing crime and instruction titled Statistique Comparée de l'État de l'Instruction et du Nombre des Crimes. These maps 'showed the departments of France shaded according to crimes against

6 Frank E. Hagan, Introduction to criminology - Theories, Methods and Criminal Behavior. $7^{\text {th }}$ edition (SAGE, 2011), 105. 
persons, crimes against property and school instruction. ${ }^{7}$ This book was a milestone as one of the first moral statistics works, which was the basis not only of the development of criminology and sociology, but of modern social science, too.

Lambert Adolphe Jacques Quetelet (1796-1874) may have been the first who took advantage of criminal statistics that were beginning to become available in the 1820 s. Originally he was a Belgian mathematician, astronomer, statistician and sociologist, but later he became the first scientific criminologist after employing a new statisticand geographic-based approach.

In his work entitled Sur l'homme et le développement de ses facultés, ou essai de physique sociale (A Treatise on Human and the Development of His Faculties) - which was written in 1835 -, he collected and analysed statistics on crime, mortality and other subjects and devised improvements in census taking. In this book '[h]e presented his conception of the »homme moyen " (»average human") as the central value about which measurements of human traits are grouped according to the normal distribution. His studies of the numerical constancy of such presumably voluntary acts as crimes stimulated extensive studies in "moral statistics " and wide discussion of free will versus social determinism. In trying to discover through statistics the causes of antisocial acts, Quetelet conceived of the idea of relative propensity to crime of specific age groups. This idea, like his homme moyen, evoked great controversy among social scientists in the $19^{\text {th }}$ century.' The statements of the two researchers drew attention to the need for examining environmental and geographical features through statistics. They considered territorial context, which they linked to other factors, which approach became a decisive starting point of the field of criminal statistics and CG.

Of course, several Hungarian studies were born in the above topic, but almost half a century later, and unfortunately this delayed development was not continuous because of the socialist governmental system of the $20^{\text {th }}$ century. The socialist view of the state and the secret management of criminal statistics hampered considerably the research in this field. ${ }^{9}$ At the same time, we can be proud of the fact that criminal and forensic statistical, furthermore geographical research has taken place already at the end of the $19^{\text {th }}$ century in our country.

One of the most prominent people of the development of Hungarian CG is the economist and statistician Béla Földes (1848-1944), who was searching for correlation between crime and geographical features. In 1889, he published an article about the statistics of crime, so he became the first person associated with a criminal geographic study in Hungary. Földes recognised the hidden possibilities in criminal statistics, which can be the inductive and the empirical basis of the study of crime. Földes also sought to reveal the individual and social processes and connections behind the data, therefore he dealt specifically with the relationship between economic conditions,

\footnotetext{
'André-Michel Guerry', Wikipedia. Available: https://en.wikipedia.org/wiki/Andr\%C3\%A9-Michel_Guerry (16. 12. 2020.)

'Adolphe Quetelet', Encyclopædia Britannica. Available: www.britannica.com/biography/Adolphe-Quetelet (20. 05. 2020.)

Szabolcs Mátyás and János Sallai, 'Kriminálgeográfia', in Tendenciák és alapvetések a bünügyi tudományok köréboól, ed by P. Ruzsonyi (Budapest: NKE RTK, 2014), 336.
} 
spatiality and crime. He used several different types of data in various categories: his system of categories includes physical, economic, intellectual, moral, legal and political factors alike. ${ }^{10}$

His work was based in particular on the data of censuses, and he identified several connections between poverty and crime. He emphasised the role of poverty, because in his opinion the low income and thus low social status is a catalyst for crime, furthermore, 'the consequences of poverty are not only individual but also social'. ${ }^{11}$ In addition, he focused on the geographical location of crime and he differentiated so-called 'endemic crimes' that are specific to a certain location. ${ }^{12}$

Földes was followed by many people, among them Albert Irk (1884-1952), who published a book entitled Kriminológia [Criminology] in 1912 about the discipline of criminology. It was the first Hungarian book which tried to systematise the trends of criminology and dealt separately with the territorial distribution of crime. $\mathrm{He}$ identified the spatial characteristics of crime as physical factors outside the human body, after he made a crime map and realised that crime was most prevalent where the natural conditions were not appropriate and the population density and literacy rate were low. ${ }^{13}$ According to Irk, the urban and rural crimes have the same attributes, but while in rapidly developing cities crime against property dominates, in the countryside crimes against life and violent crimes are more frequent. Irk wrote the following: 'The city itself is not the cause of the criminality... but in the cities there are more personal poverty without any surveillance, which can be a condition for crime. ${ }^{14}$

Interestingly, between the two world wars almost only jurists (for instance, Ervin Hacker, Károly Schnellet) dealt with this subject.

\section{Urban sociological and social-ecological explanations}

In the $20^{\text {th }}$ century the examination of local characteristics and the spatial distribution of crime became an important research area of criminology and sociology. The main focus of this research were cities where the industrial revolution of the $19^{\text {th }}$ century generated an unstoppable urbanisation. The result of this process was the growth of population, rapid growth of density, and poorer areas and factory quarters in the periphery of cities inhabited by workers. The relationships in these overcrowded polises have changed, social bonds have become loose, the cohesive capability of communities

\footnotetext{
10 Andrea Domokos, 'The Emergence of Criminology in Hungarian Criminal Sciences - late $19^{\text {th }}$-early $20^{\text {th }}$ century', Acta Juridica Hungarica 54, no 4 (2013), 338.

11 Béla Földes, A társadalmi gazdaságtan alkalmazott és gyakorlati tanai, $4^{\text {th }}$ edition (Budapest: Athenaeum Irodalmi és Nyomdai R.-T., 1907), 516.

12 Roland Perényi, ‘A bűnügyi statisztika Magyarországon a „hosszú” XIX. században', Statisztikai Szemle 85, no 6 (2007), 524-541.

13 Albert Irk, Kriminológia I. Krimináletológia - A büntett embertani, fizikai és társadalmi tényezôi (Budapest: Poltzer Zsigmond és Fia Könyvkereskedése, 1912), 262.

14 Ibid., 263.
} 
have fallen apart, and ignorance has created a new culture of behaviour. Neither the individuals, nor the society, nor the governments have prepared for these dramatic and rapid changes, so the number of deviant and abnormal acts have multiplied, alcoholism, drug use and prostitution have been unmanageable problems.

In the lack of conscious governmental intervention, the situation was no longer sustainable, but the solutions required surveys and other types of research which could present the real and deep-seated causes. This is the underlying reason for the birth of many socio-ecological, criminological and other scientific explanations.

One of these theories was the concentric zone model, which was made by Robert Ezra Park (1864-1944) and Ernest Burgess (1886-1966), members of the Chicago School. Their book, City, was published in 1925, and in this they gave a model to define how different social groups are located in a metropolitan area. The concentric zone model is one of the well-known and widely studied models in urban planning, which is based on the socio-economic status of households and the distance from central area or downtown. The different locations were defined in the form of rings around the core urban area around which the city grew, in the following way:

- Central Business District (CBD): 'The CBD is the focus of power (government, finance, business headquarters) which - incidentally - is taken as given in the model. All other activity locates relative to this centre in concentric rings. ${ }^{15}$

'The zone has tertiary activities and earns maximum economic returns. Another feature is the accessibility of the area, because of the convergence and passing of transport networks through this part from surrounding and even far places in the city. This part has tall buildings and noticeably high density to maximize the returns from land. ${ }^{16}$

This zone also known as 'loop', 'where most of the tertiary employment is located and where the urban transport infrastructure converges, making this zone the most accessible. $^{17}$

\section{- Transition Zone:}

'The mixed residential and commercial use characterizes this zone. This is located adjacent and around the CBD and is continuously changing. Another feature is the range of activities taking place like mixed land use, car parking, cafe, old buildings. This zone had a high population density when industrial activities were at their peak. Those residing in this zone were of the poorest segment and had the lowest housing condition. ${ }^{18}$

\footnotetext{
15 Richard Shearmur, 'What is an urban structure? The challenge of foreseeing 21st century spatial patterns of the urban economy', Discussion Paper, 2011. Institut National de la Recherche Scientifique, Montréal. 23.

16 'Burgess Model'. Centroid PM. Available: www.centroidpm.com/urban-management/burgess-model/ (12. 04. 2020.)

17 'The Burgess Urban Land Use Model', The Geography of Transport Systems. Available: https://transportgeography. org/?page_id=4908 (03. 12. 2020.)

18 'Burgess Model'.
} 
- Inner City / Working Class zone (Blue Collar Homes): This zone is the area of industrial workers and their families who have successfully escaped from the transition zone. Its area is also an industrial zone, so going to work is cheap for them. ${ }^{19}$

- Outer Suburbs (White Collar Homes):

'This zone had bigger houses and new development occupied by the middle class. Many of the homes are detached, and unlike single occupants of inner suburbs, families resided in these homes. Better facilities are available to the residents like parks, open spaces, shops, large gardens but this comes at an increased commuting cost.' ${ }^{20}$

\section{- Commuter Zone:}

'This is the peripheral area and farthest from the CBD, this resulted in highest commuting cost, when compared with other zones. Significant commuting cost gave the name "commuter zone" to this part. People living in this part were high-income groups, so this zone offered the highest quality of life and facilities, but at a cost of higher commuting cost.'21

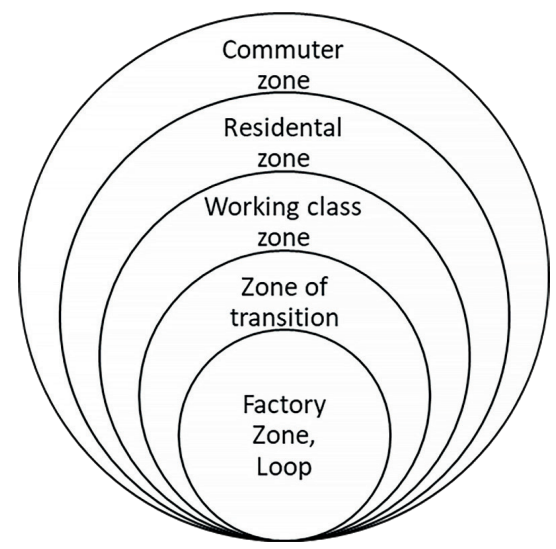

Figure 2: Concentric zone modell by Burgess. Source: edited by the author.

The next important theory was the Hoyt or Sector model, which was published in 1939 by Homer Hoyt (1895-1984). Hoyt heavily criticised the zone model, because according to him the concentric zone model is exaggeratedly USA-centric, and it is based on data of census instead of economic data.

\footnotetext{
19 Gábor Pirisi and András Trócsányi, Általános társadalom- és gazdaságföldrajz, SZTE. Available: http://tamop412a.ttk. pte.hu/fil es/foldrajz2/index.html (25. 11. 2020.)

20 'Burgess Model'.

21 Ibid.
} 
The essence of Hoyt's model is the following: cities' development and growth in sectors are not simply ring-shaped, but rather (economic) functionalities. There is little or no change in land use across sectors, as similar functions attract similar ones.

According to the Hoyt model, the spatial spread of the city is determined by the high-wage (or high rental-fee) area. This is the outermost and farthest part of downtown. It is basically the home of wealthy and affluent people with the characteristic of cleanliness; here less busy, quieter and basically big houses are built. From the CBD to the corridor properties are valuable.

The middle-class group members with middle-size income can afford higher travel costs and want better living conditions. The activities of people living in this area are various, they are not only industrial works. It has many links with $C B D$ and other industries. This area is the most important residential area.

In the low-income sector poorer groups are present. This area has narrow roads, high population density, and 'low-ventilation' houses. Roads are narrow and often linked to the industrial areas where the majority of workers in the sector work. The proximity of industries reduces travel costs and thus attracts industrial workers. The environment and living conditions are often inadequate due to the closeness of factories.

The model, of course, was formulated based on the conditions in the middle of the $20^{\text {th }}$ century, but many of the sectors defined by Hoyt can still be found; their location, formation, change and development still depend on water, air and road transport availability and opportunity.

The previous theories suggest that the basis of the expansion of a city can only consist of concentric circles, which also assumes that all settlements have a city centre, the core of the city, to which all other zones are attached. However, Chauncy D. Harris (1914-2003) and Edward L. Ullmann (1912-1976) disputed this thesis and developed their concept of polygonal cities, published in 1945. According to their model, most large cities are not organised around one single centre but are composed by the merging of several downtowns. The individual zones are thus repeated in some areas and the city is a collection of these connected zones. ${ }^{22}$

This model provided a more realistic explanation - focusing on the technological development - about the evolution of the structure of the cityscape. The model also calculated the effect of the personal transport with cars: the easier and farther movement of goods offer resettlement possibilities, thus economical activities are not centralised in one spot. Several activities move to the edge of the city, for other reasons. Such is the case of,the industrial areas, for example, which would sometimes benefit from being located away from residential areas, due to contamination problems.

Of course, other theories were published as well (by Philip Mann in 1965, by James E. Vance Jr. in 1964, or by Michael J. White in 1987), but more important is that these theories have been finally connected with the evolution of crime.

22 Adrienne Csizmady, A térinformatika a társadalomtudományban, ELTE, Available: www.tankonyvtar.hu/hu/tartalom/ tamop425/0010_2A_16_Csizmady_Adrienne_Terinformatika_a_tarsadalomtudomanyban_cimu_targyhoz_digitalis_tankonyv_fejl/adatok.html (25.11. 2020.) 
The connection between crime and zone theories was established by Clifford R. Shaw (1895-1957) and Henry D. McKay (1899-1980), when, as a result of their research, they realised that the juvenile delinquency rates are accurately in line with the zones of Park and Burgess. ${ }^{23}$

According to their social disorganisation theory, rates of crime were not evenly dispersed across time and space in the city of Chicago.

'Instead, crime tended to be concentrated in particular areas of the city, and importantly, remained relatively stable within different areas despite continual changes in the populations who lived in each area. In neighbourhoods with high crime rates, for example, the rates remained relatively high regardless of which racial or ethnic group happened to reside there at any particular time, and, as these previously »crime-prone groups « moved to lower-crime areas of the city, their rate of criminal activity decreased accordingly to correspond with the lower rates characteristic of that area. These observations led Shaw and McKay to the conclusion that crime was likely a function of neighbourhood dynamics, and not necessarily a function of the individuals within neighbourhoods.'24

'Shaw and McKay applied the concentric zone theory to juvenile delinquency. From the ecologic perspective, they observed Chicago between 1900 and 1933. As a result of their study, in their book, "Juvenile Delinquency and Urban Areas", they explained the reasons for high level crimes in the inner cities. They examined the effects of structural variables on delinquency rates. These are low economic status, ethnic heterogeneity and residential mobility. These structural factors cause social disorganization then social disorganization increases the crime and delinquency rates. ${ }^{25}$

'The four major assumptions associated with this theory are:

'(1) delinquency is the breakdown of institutional, community-based controls, ...

(2) disorganization is community-based institution that is generally caused by rapid industrialization, immigration process and urbanization, ...

(3) competition and dominance affect the performance of social institutions attractiveness of residential and business locations correspond closely to natural, ecological principles, ...

(4) these kind of areas cause the development of criminal values and traditions. ${ }^{26}$

\footnotetext{
23 Andrea Borbíró et alii (eds.), Kriminológia (Budapest: Wolters Kluwer, 2016), 135.

24 Review of the Roots of Youth Violence, Ontario, Ministry of Children, Community and Social Services. Available: www. children.gov.on.ca/htdocs/English/professionals/oyap/roots/index.aspx (03. 12. 2020.)

25 Ögretim Görevlisi, 'Testing social disorganization theory for the causes of index (major) crime incidence among Turkish juveniles', Electronic Journal of Social Sciences 13, no 51 (2014), 331.

26 Ibid., 332.
} 


\section{The development of CPTED}

After representing the development of classical basis of CG in the previous chapter, we must have a look at the history of CPTED.

Jane Jacobs (1916-2006), an American writer and activist, was the first critic of the urban planning politics. She wrote a book in 1961, called The Death and Life of Great American Cities, which was a milestone in the history of CPTED. In this book 'Jacobs saw cities as integrated systems that had their own logic and dynamism which would change over time according to how they were used. With an eye for detail, she wrote eloquently about sidewalks, parks, retail design and self-organization. She promoted higher density in cities, short blocks, local economies, and mixed uses. ${ }^{27}$

According to Jacobs the traffic of streets is an important factor of the crime. It means that the busier a street is, the safer we feel ourselves. ${ }^{28}$

The year of 1971 is the most important date in the history of CPTED, because C. Ray Jeffery (1921-2007) coined the term of this type of prophylaxis with his famous book Crime Prevention Through Environmental Design. Victoria Gibson summarised Jeffery's work as follows: 'Jeffery collectively evaluates the exploration of criminality through each discipline and underlines their importance and contribution to a new model of crime prevention. What Jeffery is suggesting in his book that we can better design environment in which humans operate, to prevent the type of behaviour we wish to control. Crucially, his research also accentuated that the notion of the environment is being a much broader notion than the typical physical built environment.

Jeffery highlighted a new approach to human behaviour in the form of behaviourism and environmentalism. He observed that crime and undesirable behaviour had previously been regarded as a biophysical phenomenon, regarded as an adaptive process to environmental conditions. From this, he emphasized the need to consider behaviour as a future orientated process in which undesirable behaviour is a result of material or social rewards, rather than a consequence of past trauma or broken families etc. To change this criminal behaviour, he argued that we must remove the environmental reinforcement which maintains such behaviour and these environmental reinforcements can be in any form.

He describes the commission of a criminal act to involve the potential consequence of punishment; therefore, the gain from the criminal act must be weighed against the risk of punishment.

Four elements of criminal behaviour are developed here:

a) The reinforcement available from the criminal act.

b) The risk involved in the commission of crime.

c) The past conditioning history of the individual involved.

d) The opportunity structure to commit the act.

\footnotetext{
'Who was Jane Jacobs?' Jane Jacobs Walk. Available: www.janejacobswalk.org/about-jane-jacobs-walk/meet-jane-jacobs (04. 04. 2020.)

28 Borbíró et alii, Kriminológia, 236-237.
} 
Whilst Jeffery's ideas were pioneering at that time, his failure to provide immediate short-term solutions resulted in his work being largely ignored and attacked by criminologists at that time.'29

The next step of the development of CPTED was the book of Oscar Newman (19352004). He wrote his book Defensible space in 1972. This is the 'dominant theoretical framework put forward to explain the unique contribution that environmental design and layout play in creating opportunities for crime'. ${ }^{30}$

According to Newman the defensible space theory has only one real purpose:

' $r$ r]estructure the physical layout of communities to allow residents to control the areas around their homes. This includes the streets and grounds outside their buildings and the lobbies and corridors within them. The programs help people preserve those areas in which they can realize their commonly held values and lifestyles. ${ }^{31}$

There are four key concepts and design principles in his theory: territoriality, surveillance, image and milieu.

Newman suggested that the physical layout can be designed to improve natural surveillance opportunities for residents. The ability of residents to casually and regularly observe the public areas in one's environment is an important factor in reducing crime in these areas and in lessening residents' fear of crime when they use these public areas. This idea is similar to the argument offered by Jane Jacobs that buildings should be oriented to provide natural surveillance of the street.

Of course, defensible space theory 'was discussed, utilised, and criticised widely by criminologists and other social scientists, as well as urban planners, law enforcement officials, and architects. Despite that, the design concepts have also been implemented in numerous communities in the United States and around the world.'32

Almost a decade later Donald Appleyard (1928-1982), who was an urban designer and theorist, observed the influence of the pedestrian traffic on crime. In 1981, in his book Livable streets, he discussed traffic control, street management, and the protection of neighbourhoods. He emphasised that '[p]eople have always lived on streets. They have been the places where children first learned about the world, where neighbours met, the social centres of towns and cities, the rallying points for revolts, the scenes of repression... The street has always been the scene of this conflict, between living and access, between resident and traveller, between street life and the threat of death. ${ }^{33}$

\footnotetext{
29 Victoria Gibson, Third Generation CPTED? Rethinking the Basis for Crime Prevention Strategies (Newcastle: Northumbria University, 2016), 33.

30 Danielle Reynald and Henk Elffers, 'The Future of Newman's Defensible Space Theory: Linking Defensible Space and the Routine Activities of Place', European Journal of Criminology 6 (2009), 26.

31 Oscar Newman, Creating Defensible Space (U.S. Department of Housing and Urban Development, Office of Policy Development and Research, 1996), 9.

32 Patrick Donally, 'Newman, Oscar: Defensible Space Theory', Encyclopedia of Criminological Theory, ed, by Francis T. Cullen and Pamela Wilcox (SAGE, 2010).

33 Donald Appleyard, Livable streets (Berkeley CA: University of California, 1981), 1.
} 
According to Appleyard the 'streets can kill the cities'. As a result of his research, he defined three type of streets: '[t]he 2,000 vehicles per day street was considered Light Street, 8,000 vehicles per day travelled in a Medium Street and 16,000 vehicles per day in a Heavy Street. His research showed that residents of Light Street had three more friends and twice as many acquaintances as the people on Heavy Street.

Further, as traffic volume increases, the space people considered to be their territory shrank. Appleyard suggested that these results were related, indicating that residents on Heavy Street had less friends and acquaintances precisely because there was less home territory in which to interact socially. ${ }^{34}$

Summarising, the first generation CPTED principles are:

a) natural surveillance

It is based on the defensible space concept, its goal is to discourage potential offenders by maximising the visibility of space and its users, thereby increasing the probability that offenders will be detected by inhabitants and other legitimate users.

b) territorial reinforcement

This principle calls for the clear demarcation of zones that are visibly controlled and influenced by the inhabitants of the surrounding space. It requires that public and private zones are clearly delineated, property lines are well defined through the use of fences, barriers and landscaping.

c) natural access control and target hardening

This recommendation focuses on the strategy of blocking off access to crime targets by using structural intervention. For instance, physical barriers, lockable gates, fences, traffic calming, CCTV and so on.

d) maintenance, place management

The image and space management strategy is aimed at the consistent maintenance and upkeep of the physical environment in order to foster a positive place image and maintain good place management practices. ${ }^{35}$

\section{The future of the relationship between CPTED and CG}

In the light of the above, first generation CPTED principles focus on the physical surroundings and on technical solutions. On the other hand, second generation CPTED principles concentrate on individuals and community. In 1998, Gregory Saville and Gerry Cleveland published an article in which they described their new approach. According to them, the CPTED experts have forgotten the essence of CPTED and they focus only on the physical design aspects. Their main question is: 'Have we forgotten that what is significant about Jacob's »eyes on the street« are not the sightlines or even the streets,

\footnotetext{
34 'Donald Appleyard', Project for Public Spaces. Available: www.pps.org/article/dappleyard (05. 05. 2020.)

35 Bonnie S. Fisher and Steven P. Lab (eds.), Encyclopedia of Victimology and crime prevention (SAGE, 2010), $220-223$.
} 
but the eyes? Jacob's synecdoche - using eyes to represent entire neighbourhoods of watchers - reminds us that what really counts is a sense of community.' ${ }^{36}$

As a result of this argument they created new, second-generation principles:

a) social cohesion and community culture

Maybe these are the most important principles, which are implemented by bringing residents together. These principles are aimed at encouraging community participation by organising social events and other activities, which promote the establishment of a network of relationships among residents. By enhancing the relationships between residents, social cohesion interventions can help foster effective network of engaged citizens that are not only able to provide guardianship in neighbourhood but also resolve conflicts within them. ${ }^{37}$

b) connectivity

It focuses on building up a positive network of relationships between neighbourhoods and external public support agencies. Initiating and sustaining relationships may require interpersonal skills, cyber and physical connectivity.

c) threshold capacity

Finally, the last component refers to the natural capacity of a neighbourhood to serve particular functions or host specific activities. This involves establishing balanced or land uses and social activities introducing social stabilisers or keeping crime generators low.

Before the birth of second-generation principles CG was not necessary in a 'CPTED process', because CPTED solutions were interpreted as general and multipurpose recommendations that could be used everywhere. The overwhelming majority of recommendations, such as transparency, lighting, or even the height of fences and bushes, as applicable crime prevention interventions, had not previously been linked to criminal contamination. As a result of the misunderstanding - mentioned by Saville -, CPTED was only interpreted as a set of technical solutions, so its application was not a prerequisite for the CG examination of the area.

The new (or maybe the right) approach of CPTED adopts the diametrically opposite point of view, when focuses on a defined community of a specific area. If we try to make safer a specific area, we must know the existing problems. Not only in relation of crime, but in relation of fear of crime, and other deviant acts and habits of community. We must reveal every circumstance and we need to understand how the community works. What kind of problems - for example traffic situations or young people, who are hanging out on the streets - bother the people? And of course, where these problems are located?

36 Gregory Saville and Gerry Cleveland, $2^{\text {ND }}$ GENERATION CPTED: An Antidote to the Social Y2K Virus of Urban Design (Washington: $3^{\text {rd }}$ International CPTED Conference, 1998), 1.

37 Hervé Borrion and Daniel Koch, 'Architecture', in Routledge Handbook of Crime Science, ed. by Richard Wortley et alii (New York: Routledge International Handbooks, Taylor\&Francis Group, 2018), 159. 
So, we must use the tools of CG and make maps, which can give us a general idea and help identify the right interventions.

\section{Summary}

In the 1990s and 2000s the theories appeared in practice and, among others, the National Institute of Crime Prevention in the USA, the International CPTED Association in Canada, the Secure by Design (SBD) in the United Kingdom were established. Unfortunately, both criminal geography research and CPTED research are lagging behind in Hungary.

As you can see above, the creation of new theories, principles and methods is endless. For example, Saville, after making the second-generation principles, started a new movement, called Safegrowth. Safegrowth is actually a new approach of CPTED, which tries to focus on people and their real problems. It is a people-based program that creates new relationships between city government and residents in order to prevent crime and planning for the future. While technology and evidence-based practice plays an important role, people who believe in CPTED and Safegrowth build community capacity with precise and measurable plans and permanent, problem-solving teams networked together throughout the city.

The basic philosophies of Safegrowth are:

- Action-Based Practice (ABP) - 'the neighbourhood, such as residents, and those with specialized expertise, such as crime prevention practitioners, academics, urban planners and police officers, have an equally important role to play in making safer and more vibrant places. ${ }^{38}$

- To-for-with-by - 'SafeGrowth is an integrated planning method for planning safe neighbourhoods based on To-For-With-By. It proceeds by delivering strategies in partnership With and independently By residents, not To or For them.'39

And this planning is based on the tools of criminal geography!

\section{REFERENCES}

'A New Language for the 21st Century'. Safegrowth. Available: www.safegrowth.org/ safegrowth-language.html (16. 12. 2020.)

'Adolphe Quetelet', Encyclopædia Britannica. Available: www.britannica.com/biography/AdolpheQuetelet (20.05. 2020.)

André-Michel Guerry'. Wikipedia. Available: https://en.wikipedia.org/wiki/Andr\%C3\%A9-Michel_ Guerry (16. 12. 2020.)

\footnotetext{
38 'A New Language for the $21^{\text {st }}$ Century'. Safegrowth. Available: www.safegrowth.org/safegrowth-language.html (16. 12. 2020.)

39 Ibid.
} 
Appleyard, Donald: Livable streets. Berkeley CA, University of California, 1981.

Barabás, A. Tünde et alii: 'Környezetszenzitív megelőzés az okos városokban'. Kriminológiai Tanulmányok 56 (2019), 121-142.

Borbíró, Andrea et alii (eds.): Kriminológia. Budapest, Wolters Kluwer, 2016.

Borrion, Hervé - Koch, Daniel: Architecture. In Routledge Handbook of Crime Science, ed. by Wortley, Richard et alii. New York, Routledge International Handbooks, Taylor\&Francis Group, 2018. DOI: https://doi.org/10.4324/9780203431405-11

'Burgess Model'. Centroid PM. Available: www.centroidpm.com/urban-management/burgess-model/ (12. 04. 2020.)

Crowe, Timothy D.: Crime prevention through environmental design: Applications of architectural design and space management concepts. $2^{\text {nd }}$ edition. National Crime Prevention Institute. Boston, Butterworth-Heinemann, 2000.

Csizmady, Adrienne: A térinformatika a társadalomtudományban. ELTE. Available: www.tankonyvtar.

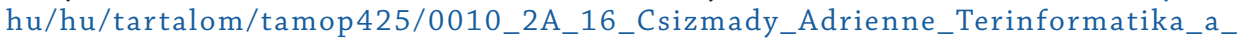
tarsadalomtudomanyban_cimu_targyhoz_digitalis_tankonyv_fejl/adatok.html (25.11. 2020.)

Domokos, Andrea: 'The Emergence of Criminology in Hungarian Criminal Sciences - late $19^{\text {th }}$-early $20^{\text {th }}$ century'. Acta Juridica Hungarica 54, no 4 (2013), 331-348. DOI: https://doi.org/10.1556/ ajur.54.2013.4.3

'Donald Appleyard', Project for Public Spaces. Available: www.pps.org/article/dappleyard (05. 05. 2020.)

Donally, Patrick G.: 'Newman, Oscar: Defensible Space Theory'. In Encyclopedia of Criminological Theory, ed, by Cullen, Francis T. - Wilcox, Pamela. SAGE, 2010. 665-668. DOI: https://doi. org/10.4135/9781412959193.n185

Fisher, Bonnie S. - Lab, Steven P. (eds.): Encyclopedia of Victimology and crime prevention. SAGE, 2010. DOI: $10.4135 / 9781412979993$

Földes, Béla: A társadalmi gazdaságtan alkalmazott és gyakorlati tanai. $4^{\text {th }}$ edition. Budapest, Athenaeum Irodalmi és Nyomdai R.-T., 1907.

Gibson, Victoria: Third Generation CPTED? Rethinking the Basis for Crime Prevention Strategies. Newcastle, Northumbria University, 2016.

Görevlisi, Ögretim: 'Testing social disorganization theory for the causes of index (major) crime incidence among turkish juveniles'. Electronic Journal of Social Sciences 13, no 51 (2014), 329-345. DOI: https://doi. org/10.17755/esosder.22159

Hagan, Frank E.: Introduction to criminology - Theories, Methods and Criminal Behavior. $7^{\text {th }}$ edition. SAGE, 2011.

Irk, Albert: Kriminológia I. Krimináletológia - A büntett embertani, fizikai és társadalmi tényezôi. Budapest, Poltzer Zsigmond és Fia Könyvkereskedése, 1912.

Mátyás, Szabolcs - Sallai, János: 'Kriminálgeográfia'. In Tendenciákés alapvetések a bünügyi tudományok köréböl, ed. by Ruzsonyi, P. Budapest, NKE RTK, 2014. 335-353.

Molnár, István Jenő: 'A bűnmegelőzés értelmezése és magyarországi fejlődése'. In A bünüldözés és a bünmegeloozés rendészettudományi tényezői. Pécs, Magyar Hadtudományi Társaság Határőr Szakosztály Szakcsoportja, 2019. 77-91.

Newman, Oscar: Creating Defensible Space. U.S. Department of Housing and Urban Development, Office of Policy Development and Research, 1996.

Perényi, Roland: ‘A bűnügyi statisztika Magyarországon a „hosszú” XIX. században'. Statisztikai Szemle 85, no 6 (2007), 524-541.

Pirisi, Gábor - Trócsányi, András. Általános társadalom- és gazdaságföldrajz. SZTE. Available: http:// tamop412a.ttk.pte.hu/fil es/foldrajz2/index.html (25. 11. 2020.)

Review of the Roots of Youth Violence. Ontario, Ministry of Children, Community and Social Services. Available: www.children.gov.on.ca/htdocs/English/professionals/oyap/roots/index.aspx (03. 12. 2020.)

Reynald, Danielle M. - Elffers, Henk: 'The Future of Newman's Defensible Space Theory: Linking Defensible Space and the Routine Activities of Place'. European Journal of Criminology 6 (2009), 25-46. DOI: https://doi.org/10.1177/1477370808098103 
Shearmur, Richard: 'What is an urban structure? The challenge of foreseeing 21st century spatial patterns of the urban economy'. Discussion Paper, 2011. Institut National de la Recherche Scientifique, Montréal.

Saville, Gregory - Cleveland, Gerry: $2^{\text {nd }}$ Generation CPTED: An Antidote to the Social Y2K Virus of Urban Design. Conference paper, Washington, $3^{\text {rd }}$ International CPTED Conference, 1998.

Tóth, Antal: A bünözés térbeli aspektusainak szociálgeográfiai vizsgálata Hajdú-Bihar megyében. $\mathrm{PhD}$ Dissertation, University of Debrecen, 2007.

'The Burgess Urban Land Use Model'. The Geography of Transport Systems. Available: https:// transportgeography.org/?page_id=4908 (03. 12. 2020.)

'Whowas Jane Jacobs?' Jane Jacobs Walk. Available: www.janejacobswalk.org/about-jane-jacobs-walk/ meet-jane-jacobs (04. 04. 2020.)

\section{ABSZTRAKT}

\section{Az építészeti bünmegelözés és a kriminálföldrajz kapcsolata \\ MOLNÁR István Jenő}

Az eredményes bünmegelözés alapja a bünözési trendek ismerete, a kriminális cselekmények alakulásának folyamatos nyomon követése. A bünözés struktúrájának, dinamikájának és terjedelmének feltérképezésére irányuló igény nem új keletü, mint ahogy a deliktumok térbeli megoszlásának és az épitészeti búnmegelőzés kapcsolatának vizsgálata sem. Az építészeti búnmegelőzés filozófiája azonban az elmúlt két évtizedben gyökeresen megváltozott, középpontba került az egyén és az egyének alkotta közösségek szerepe, bevonásuk, cselekvésre ösztönzésük szükségessége. Vajon milyen módon változott meg e paradigmaváltásnak köszönhetően a két terület viszonya? Mennyire magától értetődő a jövőben az, hogy azokon a területeken kell az építészeti búnmegelőzés eszközeit alkalmazni, ahol nagyobb búnügyi fertőzöttség tapasztalható?

Kulcsszavak: bűnmegelőzés, építészeti bűnmegelőzés, kriminálföldrajz, építészet, várostervezés 